\title{
Are dietary recommendations for the use of fish oils sustainable?
}

\author{
David J.A. Jenkins MD DSc, John L. Sievenpiper MD PhD, Daniel Pauly Dr rer nat, \\ Ussif Rashid Sumaila Dr Polit, Cyril W.C. Kendall PhD, Farley M. Mowat OC DLitt
}

$\mathrm{P}$ eople in developed countries have been encouraged in recent years to increase their intakes of fatty fish by at least $2-3$-fold. The goal is to consume adequate amounts of the long-chain polyunsaturated omega-3 fatty acids, eicosapentaenoic acid (EPA) and docosahexaenoic acid (DHA) for optimal health and prevention of major chronic diseases. Health agencies now recommend that the current average intake of $100 \mathrm{mg} / \mathrm{d}$ of omega- 3 fish oils, reported in the National Health and Nutrition Examination Survey III, ${ }^{1}$ should be raised to $1000 \mathrm{mg}$ ( 2 servings of oily fish) per week for prevention of chronic disease. ${ }^{2}$ Amounts of $250 \mathrm{mg} / \mathrm{d}^{3}$ to as high as $1000 \mathrm{mg} / \mathrm{d}$ are suggested for secondary prevention of coronary artery disease, and amounts of $2000-4000 \mathrm{mg} / \mathrm{d}$ are recommended for the management of elevated triglyceride levels. ${ }^{4}$

The main problem with this advice is that, even at current levels of fish consumption, fisheries globally have reached a state of severe crisis (Figure 1). ${ }^{5-8}$ Already, the demand from affluent and developing economies, particularly newly affluent China, cannot be met by the world's fisheries. ${ }^{6}$ Moreover, declining catches are increasingly diverted toward affluent markets rather than local ones, with dire consequences for the food security of poorer nations, islands and coastal communities. ${ }^{9}$

The collapse of global fish stocks and its socio-economic effects are therefore incongruent with the current recommendations to consume more fish oils. In this article, we examine the questions that arise from this dilemma. What is the evidence that fish oils have a role in disease prevention? How limited are supplies of fish oil? What are the environmental and socio-economic consequences of an increase in fish consumption in developed countries? Are there viable alternative sources of omega-3 fatty acids? If there are, should we focus on developing these sources as a commercially available solution?

\section{Fish oils in disease prevention}

Most of the focus on fish oils has been related to their use in preventing coronary artery disease, which has the most evidence to support it. That evidence includes both epidemiologic cohort studies and randomized controlled trials. Cohort studies are seen as largely supportive of the assumption of benefit from fish oils. ${ }^{3,10}$ However, fish eaters generally have healthier lifestyles than the rest of the population. They exercise more, smoke less and have better diets. ${ }^{11-13}$ Controlling for these variables may not allow investigators to fully under-

\section{Key points}

- International agencies concerned with health, together with medical and nutritional health communities, unanimously recommend the consumption of fish by the general public.

- The advice is based primarily on the benefits to heart function of the long-chain polyunsaturated omega-3 fatty acids in fish oils, although brain development, mental health and the prevention of cancer, autoimmune diseases and diabetes are also cited.

- Insufficient attention has been paid to individual studies and meta-analyses that fail to establish a significant benefit to health of omega-3 fatty acids.

- Insufficient attention has also been paid to the potential environmental impact of increased fish consumption, given the serious decline in global fish stocks.

- Research is needed to clarify the benefits of omega-3 fatty acids. At the same time, alternative sources of omega-3 fatty acids should be sought.

- Dietary recommendations to increase fish consumption may not be sustainable.

stand the independent influences of any one factor. Similarly, populations with high consumption of fish per capita, such as coastal fishing communities, may be more physically active than city dwellers. Limitations like these may not be great enough to dismiss the results of cohort studies that support fish oil consumption. But the magnitude of the effect - and thus the claim that fish oil consumption is essential for good health - requires further debate.

The first randomized controlled trials to demonstrate the benefit of fish oils involved the prevention of restenosis after angioplasty. Three meta-analyses performed to examine these studies concluded that fish oils do prevent restenosis. ${ }^{14-16}$ However, the most recently published meta-analysis was only able to document clinically important benefits in 5 of 12 studies. ${ }^{15} \mathrm{~A}$ 13th study was excluded due to high fish oil intake. ${ }^{17}$

Interest then shifted to studies of secondary prevention. Their results were interpreted as showing that fish oils benefit health. However, the benefit that was reported at the end of 2 years in the first randomized controlled trial,,${ }^{18}$ the Diet and

From the Risk Factor Modification Centre, St. Michael's Hospital, and the Department of Nutritional Sciences, Faculty of Medicine (Jenkins, Sievenpiper, Kendall), University of Toronto, Toronto, Ont.; the Fisheries Centre, College for Interdisciplinary Studies, University of British Columbia (Pauly, Sumaila), Vancouver, BC; the College of Pharmacy and Nutrition (Kendall), University of Saskatchewan, Saskatoon, Sask.; Port Hope, Ont. (Mowat) 
Reinfarction Trial (DART), was reversed at 3 years in a posttrial follow-up. ${ }^{19}$ The reversal may have been due to lower compliance with the dietary regimen over time.

Although this follow-up assessment of the DART results is largely criticized, ${ }^{20}$ the same criticisms have not been raised in analogous situations, such as the United Kingdom Diabetes Prospective Study, in which a significant benefit of glycemic control was seen only after the end of the trial. ${ }^{21}$

The influential Prevenzione trial in Italy ${ }^{22}$ reported only a $10 \%$ benefit in 2-way analysis and a $15 \%$ benefit in 4-way analysis for its combined outcome of all-cause mortality, nonfatal myocardial infarction or nonfatal stroke. No significant benefit was reported in the other outcome of all cardiovascular events. The most recent trial by this team of researchers, which focused on heart failure, ${ }^{23}$ reported a benefit of $8 \%$ for the combined outcome of all-cause mortality or hospital admission related to cardiovascular causes.

A study by Yokoyama and colleagues ${ }^{24}$ reported a $19 \%$ reduction in major coronary events among Japanese patients with hypercholesterolemia treated with eicosapentaenoic acid. However, it showed no difference in the secondary outcome of cardiovascular-related deaths. The authors attributed the lack of difference in mortality to the low event rate because of the high fish intake in the population. ${ }^{24}$ Presumably, this same logic would suggest that there should have been no effect on nonfatal cardiovascular disease either.

Finally, in the study known as DART-2 that examined the benefit of dietary advice to men with angina, patients who were advised to consume fish oil showed an increased risk of cardiac death. ${ }^{25}$ The study's unexpected finding is routinely explained away by extensive criticism of its methodologic quality. It is faulted for poor assessment of compliance, a lack of blinding and multiple dietary changes during the trial. ${ }^{26-28}$

Yet some of the same criticisms apply to studies reporting favourable effects of fish oils. The Italian Prevenzione trial ${ }^{22}$ was unblinded, and neither it nor the heart failure trial by the same team of researchers measured eicosapentaenoic acid levels for compliance. 22,23 The study by Yokoyama and colleagues was also unblinded. ${ }^{24}$ More than pointing to methodologic deficiencies, the angina trial data ${ }^{25}$ keep open the possibility that there may be a subgroup of patients who fare worse on a diet high in fish oils.

The most recent interest in fish oils is focused on its effect in stabilizing the electrical activity of the heart. In this respect, secondary analyses of the data from the prevenzione trial $^{22}$ showed a $36 \%-45 \%$ reduction in sudden cardiac death, depending on the approach to the analysis. This finding has been interpreted as key evidence for the value of fish oils in preventing fatal ventricular arrhythmias. However, this benefit was not seen in patients with heart failure, ${ }^{23}$ hypercholesterolemia ${ }^{24}$ or angina. ${ }^{25}$

Studies involving implantable cardioverter defibrillators provide interesting insights into mechanisms of action while controlling for the adverse consequences of arrhythmias, such as cardiac death. In a meta-analysis of 3 major studies of implantable defibrillators, ${ }^{29}$ significant heterogeneity was documented, with some individuals benefiting while others were adversely affected. Overall, these studies were inconclusive.

Meta-analyses, just as individual trials, are divided in terms of the value of fish oils for the prevention of coronary artery disease..$^{3,30,31}$ One recent meta-analysis concluded that, although no significant harms were observed with increased fish oil consumption, the data were too few to rule them out. ${ }^{31}$ A second meta-analysis concluded that omega-3 fatty acids

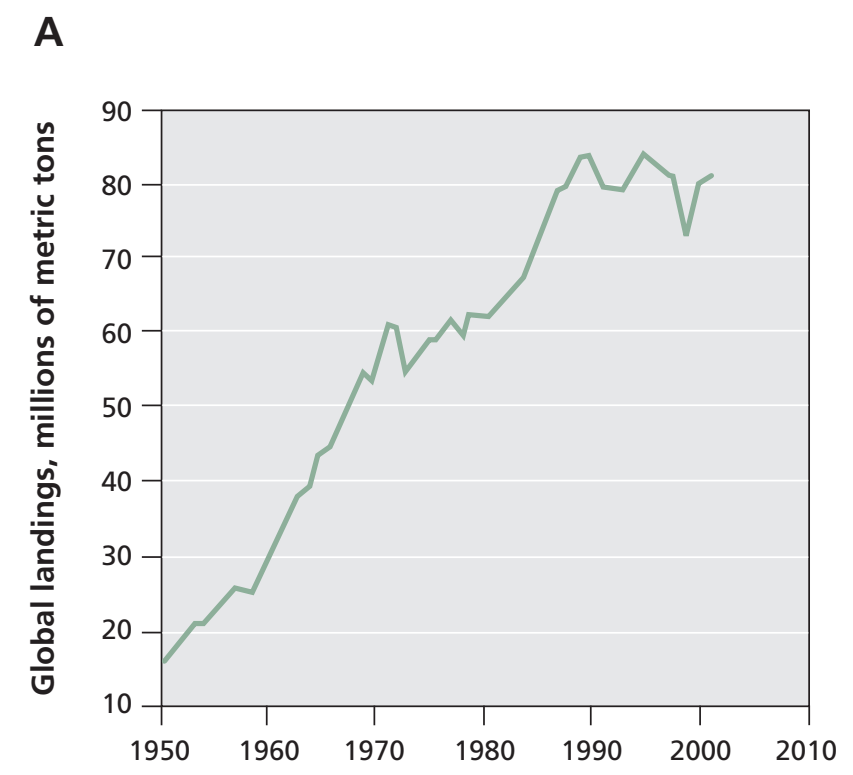

B

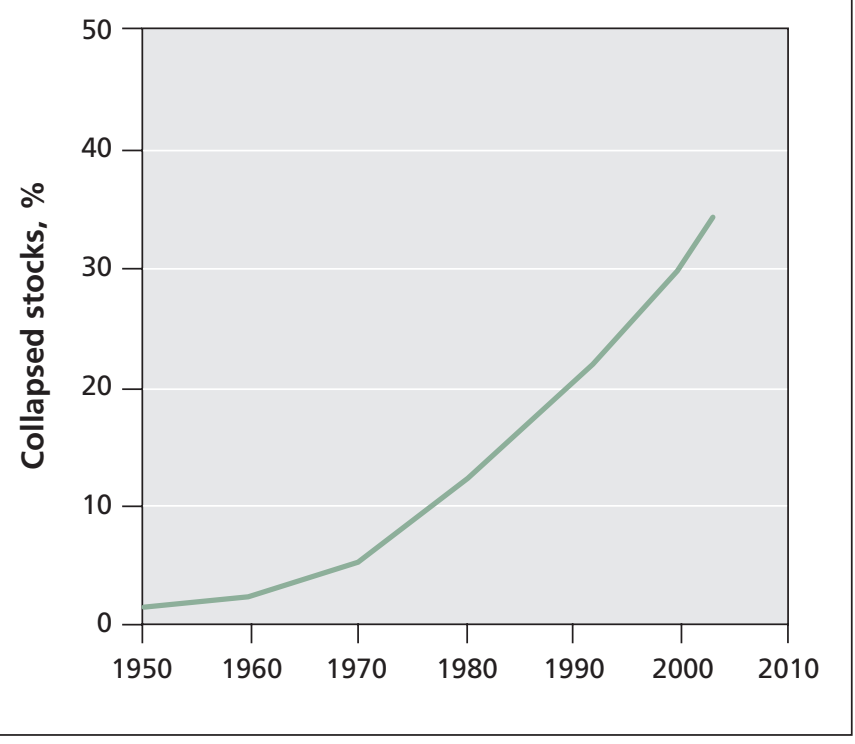

Figure 1: Trends observed in global fisheries. (A) Trends observed in global catch from 1950 to 2000, after correction for overreporting by China. ${ }^{5}$ (B) Exploited stocks ( $n<10$ 000; in 64 large marine ecosystems) whose catches declined to $10 \%$ of their historic maximum yield, signifying collapse. ${ }^{8,47,48}$ 
improved overall mortality by $17 \%$, compared with $15 \%$ with the use of statins. ${ }^{3}$ But this assessment did not include the large trial by Yokoyama and colleagues ${ }^{24}$ that showed no survival advantage among patients with coronary artery disease.

At best, fish oils are likely only one factor among others that may reduce the risk of coronary artery disease. Certain groups of people who are otherwise healthy and do not eat fish, such as vegetarians, are not at increased risk of heart disease..$^{32}$

\section{Other potential health benefits}

Despite interest in the effects of fish oils on neurologic development, ${ }^{33-35}$ mental health, ${ }^{36-39}$ dementia, ${ }^{40}$ cancer, ${ }^{41}$ autoimmune diseases including Crohn disease, ${ }^{42}$ ulcerative colitis, ${ }^{43}$ asthma ${ }^{44}$ multiple sclerosis ${ }^{45}$ and diabetes ${ }^{46}$ no meta-analyses have concluded that fish oils are of benefit, with the exception of one. That meta-analysis reported that maternal intake of docosahexaenoic acid is beneficial for early neurologic development. ${ }^{3}$ However, many of these analyse ${ }^{35-40,42-46}$ have concluded that the existing studies are too few and too short to draw definite conclusions.

\section{How limited are our supplies of fish?}

In contrast to the uncertainty over the value of omega- 3 fish oils in the scientific literature, there is little doubt about the gravity of the fisheries crisis and the prospect of ongoing collapses of fish stocks. There is scientific consensus about the rapid worldwide decline of fish stocks. Notably, and despite increasing fishing effort, global catches have been in decline since the late 1980s (Figure 1A), ${ }^{5}$ and the number of collapsed stocks has been increasing exponentially since 1950 (Figure 1B). ${ }^{8,47,48}$ There are also over 100 confirmed cases of extinctions of marine populations in the world's oceans. ${ }^{49}$

When projected forward, these trends imply the collapse of all commercially exploited stocks by midcentury. ${ }^{7.8}$ Yet the dire status of fisheries resources is largely unrecognized by the public, who are both encouraged to eat more fish and are misled into believing that we still sail in the sea of plenty. ${ }^{50}$ Indeed, the species that Westerners are supposed to eat in increasing amounts have stocks that are already under tremendous pressure (e.g., yellowfin tuna, the basis of the much recommended North American "tuna-fish sandwich" have collapsed, sometimes spectacularly, such as cod off the coast of northeastern Canada. ${ }^{52}$

\section{Socio-economic effects}

The combined effect of rising demand and the collapse of local fisheries is that developed countries such as the United States, Japan and members of the European Union are increasingly importing large quantities of seafood from developing countries. The proportion of fish and fish products being traded on the global market is $40 \%$ versus $5 \%$ for rice..$^{53}$ This demand puts intense pressure on developing countries either to allow access of foreign fishing fleets to their coastal fishing grounds $\mathrm{s}^{5,55}$ or to export their fish to foreign markets. In either case, the local markets of developing countries, ${ }^{53}$ where basic nutrition and health are challenges (such as nations in West Africa),, 956 are deprived of an important source of protein for the sake of the developed world, whose major problems are overnutrition and physical inactivity.

\section{Fish farms and aquaculture as solutions}

Fish farming is mainly a distraction in this context, since it is unlikely to resolve the problem. Aquaculture, as practised in developed countries, consists mainly of raising carnivorous fish (e.g., salmon, bluefin tuna and sea bass) on a high-protein diet of fishmeal and fish oils. That diet is in turn derived from perfectly edible smaller fish, which supply the omega- 3 fatty acids found in farmed fish. ${ }^{57}$ Because the aquaculture industry cannot eliminate fishery-derived products such as herring, sardines, anchovies and other edible small fishes from the diet of farmed fish, the paradoxical situation has emerged that increased aquaculture production leads to increased pressure on wild fish stock. ${ }^{58}$ The equation is an unfavourable one for fisheries: it takes $2.5-5 \mathrm{~kg}$ of feed fish to make $1 \mathrm{~kg}$ of farmed carnivorous fish. ${ }^{58}$

Another constraint on the expansion of farming of carnivorous fish is the environmental damage associated with its operations. The damage includes not only the destruction and pollution through nitrogenous waste of habitats for other fish, but also harmful algae blooms and the transmission of parasites from farmed fish to wild fish populations. ${ }^{58,59}$ Aquaculture is therefore becoming increasingly regulated and is gradually running out of suitable sites. ${ }^{60,61}$

\section{Contaminants in fish}

Fish, especially predatory fish such as swordfish, shark, golden bass and king mackerel, may accumulate methylmercury, polychlorinated biphenols (PCBs) and dioxins. ${ }^{62,63}$ Worldwide sources of farmed salmon have been shown to contain higher levels of organochlorine contaminants, such as PCBs, dioxins, toxaphene and dieldrin, than wild salmon. ${ }^{64}$ Industrial activity has been largely responsible for increasing the levels of these toxins in lakes, rivers and coastal regions of the sea. ${ }^{62}$ PCBs and dioxins have gained attention as carcinogens with genomic effects.

Mercury exposure is known to cause neurologic damage to parts of the human body, including conduction tissue in the heart. It can also damage the liver and kidneys by bonding to sulfhydryl groups of protein in the body's antioxidant defense system, where it prevents the quenching of free radicals. ${ }^{3}$ A recent, comprehensive meta-analysis concluded that any risks associated with fish consumption are far outweighed by the benefits of increased omega- 3 fatty acid intake. ${ }^{3,62,63}$ Nevertheless, the study's authors conceded that intakes of certain fish should be limited in the diets of pregnant women and children to minimize exposure to methylmercury. Earlier in 2004, the US Food and Drug Administration suggested that women of child-bearing age, pregnant women, nursing mothers and very young children should not eat long-lived predatory fish. Instead, it recommended that they eat up to $12 \mathrm{oz}(340 \mathrm{~g})$ per week, or 2 average meals, of 
other fish and shellfish, including no more than $6 \mathrm{oz}(170 \mathrm{~g})$ per week of albacore tuna. It also advised consumers to consult local advisories. ${ }^{63}$ In the same year, Health Canada updated a consumer information document about fish consumption, advising that predatory fish, including fresh and frozen tuna but not canned tuna, be eaten only occasionally. ${ }^{62}$ No advisory has been issued regarding PCB or dioxin exposure from fish consumption.

\section{Alternative sources of omega-3 fatty acids}

Alternatives to fish oils exist or are being developed. ${ }^{65}$ Docosahexaenoic acid and eicosapentaenoic acid are produced by unicellular organisms. Docosahexaenoic acid is currently produced from the algae Crypthecodinium cohnii for use in infant formula to promote brain development. ${ }^{66,67}$ Major corporations are also working on genetically modified yeast and plants that could serve as factories for the synthesis of longchain omega-3 fatty acids, including eicosapentaenoic acid. ${ }^{68,69}$ In addition, the plant-derived shorter $\mathrm{n}-3$ polyunsaturated fatty acids (alpha-linolenic acid) may reduce the risk of reinfarction and may be a substitute for the longer-chain n-3 fatty acids in promoting heart health in populations in which long-chain n-3 fatty acid intake is low. ${ }^{70-72}$

If further research leads to guidelines for specific dosages and indications of fish oils, then these alternative sources need to be properly evaluated in clinical trials before widespread use.

\section{Conclusions}

Until renewable sources of long-chain omega-3 fatty acids derived from plant, algae, yeast or other unicellular organisms - become more generally available, it would seem responsible to refrain from advocating to people in developed countries that they increase their intake of long-chain omega-3 fatty acids through fish consumption. The evidence for the comprehensive benefits of increased fish oil consumption is not as clear-cut as protagonists suggest, including the strongest evidence to date that indicates a $15 \%$ benefit in the prevention of cardiovascular disease,$^{22}$ which itself may be reduced further if sustainable lifestyle changes were adopted as currently recommended. The evidence is even less convincing for the benefits of fish oil for growth and brain development in infants, mental health, and the prevention of dementia, cancer, inflammatory bowel disease and diabetes.

Even if the evidence were more compelling, the development of dietary guidelines that may have large-scale environmental consequences does not seem wise. An assessment of the environmental impact of such guidelines should be considered before the guidelines are issued, as it should for all clinical and public health recommendations that include dietary interventions. ${ }^{73,74}$ The environmental threat posed by an increase in fish consumption has now become obvious. Aquaculture does not appear to be a viable answer, and further endangering the food supply in developing countries clearly has harmful implications.

It is vital, therefore, that we continue with studies aimed at clarifying the benefits of omega-3 fatty acids. It is equally crucial that we continue to develop and evaluate alternative sources of omega-3 fatty acids that are sustainable.

\section{This article has been peer reviewed.}

Competing interests: David Jenkins has served on the scientific advisory board for or received research support, consultant fees or honoraria from Barilla, Solae, Unilever, Haine Celestial, Loblaws Inc., Sanitarium Company, Herbalife International, Pacific Health Laboratories Inc., Metagenics/ MetaProteomics, Bayer Consumer Care, Oldways Preservation Trust, Almond Board of California, California Strawberry Commission, Orafti, and the Canola and Flax Councils of Canada. No competing interests declared by John Sievenpiper, Daniel Pauly, Ussif Rashid Sumaila, Cyril Kendall or Farley Mowat.

Contributors: David Jenkins had the original idea for the commentary and drafted the manuscript. John Sievenpiper gathered the references, produced the figure and helped draft the manuscript. Daniel Pauly and Ussif Rashid Sumaila drafted the sections on the decline of fisheries, socio-economic effects and aquaculture, and revised significant intellectual content related to the other sections. Cyril Kendall and Farley Mowat revised significant intellectual content. All of the authors approved the final manuscript submitted for publication.

\section{REFERENCES}

1. Ervin RB, Wright JD, Wang CY, et al. Dietary intake of fats and fatty acids for the United States population: 1999-2000. Adv Data 2004;Nov 8:1-6.

2. Joint WHO/FAO Expert Consultation on Diet, Nutrition and the Prevention of Chronic Diseases. Diet, nutrition, and the prevention of chronic diseases [WHO technical report series, 916]. Geneva (Switzerland): The World Health Organization; 2003.

3. Mozaffarian D, Rimm EB. Fish intake, contaminants, and human health: evaluating the risks and the benefits. JAMA 2006;296:1885-99.

4. Lichtenstein AH, Appel LJ, Brands M, et al. Diet and lifestyle recommendations revision 2006: a scientific statement from the American Heart Association Nutrition Committee. Circulation 2006;114:82-96.

5. Watson R, Pauly D. Systematic distortions in world fisheries catch trends. Nature 2001;414:534-6.

6. Sumaila UR, Khan A, Watson R, et al. The World Trade Organization and global fisheries sustainability. Fish Res 2007;88:1-4

7. Pauly D, Alder J, Bennett E, et al. The future for fisheries. Science 2003;302:1359-61.

8. Worm B, Barbier EB, Beaumont N, et al. Impacts of biodiversity loss on ocean ecosystem services. Science 2006;314:787-90.

9. Alder J, Rashid Sumaila U. Western Africa: a fish basket of Europe past and present. J Environ Dev 2004;13:156-78.

10. Hu FB, Bronner L, Willett WC, et al. Fish and omega-3 fatty acid intake and risk of coronary heart disease in women. JAMA 2002;287:1815-21.

11. Iso H, Rexrode KM, Stampfer MJ, et al. Intake of fish and omega-3 fatty acids and risk of stroke in women. JAMA 2001;285:304-12.

12. Morris MC, Manson JE, Rosner B, et al. Fish consumption and cardiovascular disease in the physicians' health study: a prospective study. Am J Epidemiol 1995; 142:166-75.

13. Ascherio A, Rimm EB, Stampfer MJ, et al. Dietary intake of marine n-3 fatty acids, fish intake, and the risk of coronary disease among men. $N$ Engl J Med 1995;332:977-82.

14. Gapinski JP, VanRuiswyk JV, Heudebert GR, et al. Preventing restenosis with fish oils following coronary angioplasty. A meta-analysis. Arch Intern Med 1993;153: 1595-601.

15. Balk EM, Lichtenstein AH, Chung M, et al. Effects of omega-3 fatty acids on coronary restenosis, intima-media thickness, and exercise tolerance: a systematic review. Atherosclerosis 2006;184:237-46.

16. O'Connor GT, Malenka DJ, Olmstead EM, et al. A meta-analysis of randomized trials of fish oil in prevention of restenosis following coronary angioplasty. Am J Prev Med 1992;8:186-92.

17. Leaf A, Jorgensen MB, Jacobs AK, et al. Do fish oils prevent restenosis after coronary angioplasty? Circulation 1994;90:2248-57

18. Burr ML, Fehily AM, Gilbert JF, et al. Effects of changes in fat, fish, and fibre intakes on death and myocardial reinfarction: diet and reinfarction trial (DART). Lancet 1989;2:757-61.

19. Ness AR, Hughes J, Elwood PC, et al. The long-term effect of dietary advice in men with coronary disease: follow-up of the Diet and Reinfarction trial (DART). Eur J Clin Nutr 2002;56:512-8.

20. Brouwer IA, Geelen A, Katan MB. n-3 Fatty acids, cardiac arrhythmia and fatal coronary heart disease. Prog Lipid Res 2006;45:357-67.

21. Holman RR, Paul SK, Bethel MA, et al. 10-year follow-up of intensive glucose control in type 2 diabetes. N Engl J Med 2008;359:1577-89.

22. Dietary supplementation with $n-3$ polyunsaturated fatty acids and vitamin $E$ after 
myocardial infarction: results of the GISSI-Prevenzione trial. Gruppo Italiano per lo Studio della Sopravvivenza nell'Infarto miocardico. Lancet 1999:354:447-55.

23. Gissi-Hf Investigators. Effect of n-3 polyunsaturated fatty acids in patients with chronic heart failure (the GISSI-HF trial): a randomised, double-blind, placebocontrolled trial. Lancet 2008;372:1223-30.

24. Yokoyama M, Origasa H, Matsuzaki M, et al. Effects of eicosapentaenoic acid on major coronary events in hypercholesterolaemic patients (JELIS): a randomised open-label, blinded endpoint analysis. Lancet 2007;369:1090-8.

25. Burr ML, Ashfield-Watt PA, Dunstan FD, et al. Lack of benefit of dietary advice to men with angina: results of a controlled trial. Eur J Clin Nutr 2003;57:193-200.

26. He K, Song Y. Risks and benefits of omega 3 fats: a few thoughts on systematic review. BMJ 2006;332:915; discussion 915-6.

27. Geleijnse JM, Brouwer IA, Feskens EJ. Risks and benefits of omega 3 fats: health benefits of omega 3 fats are in doubt. BMJ 2006;332:915; discussion 915-6.

28. Effects of omega-3 fatty acids on cardiovascular disease [summary]. Evidence report/Technology assessment no. 94. AHRQ pub. no. 04-E009-1. Rockville (MD): US Department of Health and Human Services; 2004. Available: www.ahrq.gov /clinic/epcsums/o3cardsum.htm (accessed 2008 Nov. 18).

29. Jenkins DJ, Josse AR, Beyene J, et al. Fish-oil supplementation in patients with implantable cardioverter defibrillators: a meta-analysis. CMAJ 2008;178:157-64.

30. Bucher HC, Hengstler P, Schindler C, et al. n-3 Polyunsaturated fatty acids in coronary heart disease: a meta-analysis of randomized controlled trials. Am J Med 2002;112:298-304.

31. Hooper L, Thompson RL, Harrison RA, et al. Risks and benefits of omega 3 fats for mortality, cardiovascular disease, and cancer: systematic review. BMJ 2006; 332:752-60.

32. Key TJ, Fraser GE, Thorogood M, et al. Mortality in vegetarians and non-vegetarians: a collaborative analysis of 8300 deaths among 76000 men and women in five prospective studies. Public Health Nutr 1998;1:33-41.

33. Cohen JT, Bellinger DC, Connor WE, et al. A quantitative analysis of prenatal intake of n-3 polyunsaturated fatty acids and cognitive development. Am J Prev Med 2005;29:366-74.

34. Simmer K, Schulzke SM, Patole S. Longchain polyunsaturated fatty acid supplementation in preterm infants. Cochrane Database Syst Rev 2008;(1):CD000375.

35. Simmer K, Patole SK, Rao SC. Longchain polyunsaturated fatty acid supplementation in infants born at term. Cochrane Database Syst Rev 2008;(1):CD000376.

36. Appleton KM, Hayward RC, Gunnell D, et al. Effects of n-3 long-chain polyunsaturated fatty acids on depressed mood: systematic review of published trials. Am J Clin Nutr 2006;84:1308-16.

37. Lin PY, Su KP. A meta-analytic review of double-blind, placebo-controlled trials of antidepressant efficacy of omega-3 fatty acids. J Clin Psychiatry 2007;68:1056-61.

38. Joy CB, Mumby-Croft R, Joy LA. Polyunsaturated fatty acid supplementation for schizophrenia. Cochrane Database Syst Rev 2006;(3):CD001257.

39. Montgomery P, Richardson AJ. Omega-3 fatty acids for bipolar disorder Cochrane Database Syst Rev 2008;(2):CD005169.

40. Lim WS, Gammack JK, Van Niekerk J, et al. Omega 3 fatty acid for the prevention of dementia. Cochrane Database Syst Rev 2006;(1):CD005379.

41. MacLean $\mathrm{CH}$, Newberry SJ, Mojica WA, et al. Effects of omega-3 fatty acids on cancer risk: a systematic review. JAMA 2006;295:403-15.

42. Turner D, Zlotkin SH, Shah PS, et al. Omega 3 fatty acids (fish oil) for maintenance of remission in Crohn's disease. Cochrane Database Syst Rev 2007; (2):CD006320

43. Turner D, Steinhart AH, Griffiths AM. Omega 3 fatty acids (fish oil) for maintenance of remission in ulcerative colitis. Cochrane Database Syst Rev 2007;(3) CD006443.

44. Woods RK, Thien FC, Abramson MJ. Dietary marine fatty acids (fish oil) for asthma in adults and children. Cochrane Database Syst Rev 2002;(3):CD001283.

45. Farinotti M, Simi S, Di Pietrantonj C, et al. Dietary interventions for multiple sclerosis. Cochrane Database Syst Rev 2007;(1):CD004192.

46. Hartweg J, Perera R, Montori V, et al. Omega-3 polyunsaturated fatty acids (PUFA) for type 2 diabetes mellitus. Cochrane Database Syst Rev 2008;(1): CD003205.

47. Costello C, Gaines SD, Lynham J. Can catch shares prevent fisheries collapse? Science 2008;321:1678-81

48. The state of world fisheries and aquaculture 2006. Rome (Italy): Fisheries and Aquaculture Department, Food and Agriculture Organization of the United Nations; 2007.

49. Dulvy N, Sadovy Y, Reynolds JD. Extinction vulnerability in marine populations Fish Fishery 2003;4:25-64.

50. Sygo J. Get your omega-3s from the sea. Essential fatty acids: You gotta eat "em to get 'em. National Post [Toronto] 2008 Feb. 12. Available: www.nbsga.com/media _articles/natpost\%20article\%20omega\%203.pdf (accessed 2009 Jan. 5).

51. Myers RA, Worm B. Rapid worldwide depletion of predatory fish communities. Nature 2003;423:280-3.

52. Walters C, Maguire JJ. Lessons for stock assessment from the Northern stock collapse. Review Fish Biol Fishery 1996;6:125-37.

53. Alder J, Watson R. Fisheries globalization: fair trade or piracy. In: Taylor WW, Schetcher MG, Wolfson LG, editors. Globalization: effects on fisheries resources. Cambridge (UK): Cambridge University Press; 2007. p. 21-46.

54. Kaczynski VM, Fluharty DL. European policies in West Africa: Who benefits from fisheries agreements? Marine Policy 2002;26:75-93.

55. Ilnyckyj M. The legality and sustainability of European Union fisheries policy in West Africa. MIT International Rev. 2007:32-41. Available: http://web.mit.edu /mitir/2007/spring/fisheries.html (accessed 2009 Jan. 5).

56. Atta-Mills J, Alder J, Rashid Sumaila U. The decline of a regional fishing nation: the case of Ghana and West Africa. Nat Resource Forum 2004;28:13-21.

57. Tacon AGJ, Hasan MR, Subasinghe RP. Use of fishery resources as feed inputs for aquaculture development: trends and policy implications FAO Fisheries Circular no. 1018. Rome (Italy): Food and Agriculture Organization of the United Nations; 2006. Available: ftp://ftp.fao.org/docrep/fao/009/a0604e/a0604e00.pdf (accessed 2009 Jan. 5).

58. Naylor RL, Goldburg RJ, Primavera JH, et al. Effect of aquaculture on world fish supplies. Nature 2000;405:1017-24.

59. Krkosek M, Ford JS, Morton A, et al. Declining wild salmon populations in relation to parasites from farm salmon. Science 2007;318:1772-5.

60. Liu Y, Rashid Sumaila U. Can farmed salmon production keep growing? Marine Policy 2008:32:497-501.

61. Bjorndal T. The competitiveness of the Chilean salmon aquaculture industry Aquaculture Economics Management 2002;6:97-116.

62. It's your health: mercury and human health. Ottawa (ON): Health Canada; 2004 Available: www.hc-sc.gc.ca/hl-vs/alt_formats/pacrb-dgapcr/pdf/iyh-vsv/environ /merc2008-eng.pdf (accessed 2008 Nov. 18).

63. What you need to know about mercury in fish and shellfish. 2004 EPA and FDA advice for women who might become pregnant, women who are pregnant, nursing mothers, young children. Rockville (MD): US Department of Health and Human Services and US Environmental Protection Agency; 2004. Available: www.epa .gov/waterscience/fish/advice/advisory.pdf (accessed 2008 Nov. 18).

64. Hites RA, Foran JA, Carpenter DO, et al. Global assessment of organic contaminants in farmed salmon. Science 2004;303:226-9.

65. Surette, ME. The science behind dietary omega- 3 fatty acids. CMAJ Jan. 2008; 178:177-80.

66. Innis SM. Dietary (n-3) fatty acids and brain development. J Nutr 2007;137:855-9.

67. Cunnane SC, Crawford MA. Survival of the fattest: fat babies were the key to evolution of the large human brain. Comp Biochem Physiol A Mol Integr Physiol 2003;136:17-26.

68. Damude HG, Kinney AJ. Engineering oilseeds to produce nutritional fatty acids. Physiol Plant 2008;132:1-10.

69. Damude HG, Zhang H, Farrall L, et al. Identification of bifunctional delta12/omega3 fatty acid desaturases for improving the ratio of omega3 to omega6 fatty acids in microbes and plants. Proc Natl Acad Sci U S A 2006;103:9446-51.

70. Mozaffarian D, Ascherio A, Hu FB, et al. Interplay between different polyunsaturated fatty acids and risk of coronary heart disease in men. Circulation. 2005;111(2):157-64

71. de Lorgeril M, Salen P, Martin JL, et al. Mediterranean diet, traditional risk factors, and the rate of cardiovascular complications after myocardial infarction: final report of the Lyon Diet Heart Study. Circulation. 1999;99:779-85.

72. Campos H, Baylin A, Willett WC. Alpha-linolenic acid and risk of nonfatal acute myocardial infarction. Circulation. 2008;118(4):339-45.

73. Food Standards Agency. Agency consulting on sustainable fish advice [press release]. London (UK): The Agency; 2009 Jan. 6. Available: www.food.gov.uk /news/newsarchive/2009/jan/fish (accessed 2009 Feb. 20).

74. Brunner E. Oily fish and omega 3 fat supplements. BMJ 2006;332:739-740.

Correspondence to: Dr. David J. Jenkins, Risk Factor

Modification Centre, St. Michael's Hospital, Ste. 6133,

61 Queen St. E, Toronto ON M5C 2T2; fax 416-867-7495;

cyril.kendall@utoronto.ca 